\title{
A cross-sectional study of acute dengue infection in paediatric clinics in Cameroon
}

\author{
Salomon Bonsi Tchuandom,3, Jules Colince Tchadji, ${ }^{2,4}$, Thibau Flaurant Tchouangueu ${ }^{1,2}$, Monique Zambo Biloa ${ }^{5}$, \\ Etienne Philémon Atabonkeng ${ }^{1}$, Marcelle Irina Miste Fumba ${ }^{6}$, Eithel Sylvian Massom ${ }^{5}$, Godwin Nchinda ${ }^{2}$ and \\ Jules-Roger Kuiate ${ }^{1 *}$ (D)
}

\begin{abstract}
Background: Dengue fever is the world's fastest spreading mosquito borne viral infection. It is prevalent throughout both subtropical and tropical region, and affects over 128 countries. Dengue virus (DENV) infection poses a serious global public health challenge to three billion people, resulting in approximately 200 million cases of morbidity and 50,000 cases of mortality annually. In Cameroon like in most sub-Saharan African countries, DENV infection occur concurrently with other infectious diseases whose symptoms often overlap, rendering differential diagnosis challenging. This study aims at determining the frequency of acute dengue among febrile children under 15 years attending hospitals in some areas of Cameroon.

Methods: A total of 961 children under the age of 15 were recruited in a cross-sectional study using systematic sampling technique and by selecting each subject out of the three. The study was conducted in 10 public health centers in Cameroon. Demographic data and risk factors of the subjects were obtained using well-structured questionnaires. Dengue virus NS1 antigen, IgM and lgG were analysed using a Tell me fast ${ }^{\oplus}$ Combo Dengue NS1-lgG/IgM Rapid Test. An in-house ELISA test for dengue specific IgM antibody was equally performed for confirmation. Descriptive statistical analysis was performed using Graph pad version 6.0.

Results: A prevalence of $6.14 \%$ acute dengue virus infection was observed among children with febrile illness with a significant difference $(p=0.0488)$ between males $(4.7 \%)$ and females $(7.7 \%)$. In addition, children who reportedly were unprotected from vectors, showed a comparatively higher prevalence of the disease seropositivity than those practicing protective measures.

Conclusion: DENV infection therefore is an important cause of fever among children in Cameroon. Thus, there is a need to include differential screening for DENV infections as a tool in the management of fever in children in the country.
\end{abstract}

Keywords: Fever, Acute dengue virus, Serologic markers, Children, Febrile illness, Cameroon

\footnotetext{
* Correspondence: jrkuiate@yahoo.com

'Department of Biochemistry, University of Dschang, Dschang, Cameroon

Full list of author information is available at the end of the article
}

(c) The Author(s). 2019 Open Access This article is distributed under the terms of the Creative Commons Attribution 4.0 International License (http://creativecommons.org/licenses/by/4.0/), which permits unrestricted use, distribution, and reproduction in any medium, provided you give appropriate credit to the original author(s) and the source, provide a link to the Creative Commons license, and indicate if changes were made. The Creative Commons Public Domain Dedication waiver (http://creativecommons.org/publicdomain/zero/1.0/) applies to the data made available in this article, unless otherwise stated. 


\section{Background}

Dengue, also known as "tropical flu," is a viral disease transmitted to humans by Aedes mosquitoes [1]. This virus has four known circulating serotypes worldwide. A study carried out by Kamgang et al. (2017) [2] describes the presence of the Aedes species in some regions in Cameroon and others demonstrate that this vector bites only during the day [3-6]. Nearly three billion people live in high-risk areas, making dengue a significant public health problem. This infection is responsible for very high mobility and mortality in urban and suburban areas of high endemicity [7].

Since 2010, several African countries have suffered epidemic episodes of dengue including Tanzania, Zanzibar, the Comores, Benin, Cap Verde, Angola, Kenya, Somalia, Ivory Coast, Burkina Faso, Egypt and Nigeria $[8,9]$. Sporadic DENV outbreaks have been reported in Nigeria since 1960 [10]. Cameroon shares many kilometers of borders with Nigeria and exchanges of goods and people has increasingly been growing in recent years [11]. The first identification of DENV in Cameroon was in 1987 [12], but several cases may remain undiagnosed, misdiagnosed or confused with other tropical diseases [7].

Classically, dengue occurs suddenly after 2 to 7 days of incubation with the onset of a high fever often accompanied by headache, nausea, vomiting, joint and muscle pain and a rash similar to that of measles. After 3 to 4 days, a brief remission is observed, and then the symptoms intensify before regressing rapidly after one week [13, 14]. In some cases, the disease can progress to severe forms: haemorrhagic dengue fever and dengue fever with shock syndrome that is fatal $[13,15,16]$. There is a need for early diagnosis of dengue infection since the early diagnosis of the disease can prevent fatal cases. The early diagnosis of dengue is based on the detection of the NS1 antigen, while the search for IgM antibodies can only be done after the 6th day after the onset of fever [17].

Confirmation of the diagnosis can be direct by detection of viral genomic DNA or its SN1 antigen, or indirect by detection of specific antibodies (IgM and $\operatorname{IgG}$ ) in the blood. This may permit to distinguish acute primary and acute secondary dengue infections [18]. Early diagnosis can be obtained by gene amplification (RT-PCR) or by detection of NS1 antigen of the virus [18-21]. NS1 antigen is a glycoprotein protein detected from the first to the fifth day after the appearance of clinical signs by immunoenzymatic technique or immunochromatographic [18, 20, 22]. The viability and replication of the virus seems to depend on this protein $[20,23]$. It stimulates a strong humoral response [24]. NS1 antigen is detectable in blood from first day after the onset of fever up to day 7, and still detectable in the presence of IgM antibodies, and when viral RNA is negative by RT-PCR [13, 21]. Simultaneous detection of NS1protein and IgM antibodies markers is useful to diagnose acute dengue infection [7, 25, 26]. This study therefore aims to determine the frequency of acute dengue infection among febrile children under 15 years attending hospitals in some selected areas of Cameroon.

\section{Methods}

\section{Study and research design}

This study was carried out in 10 health centers located in five regions of Cameroon as previously described [27].

\section{Description of study sites}

The study was conducted in semi-urban areas (district hospitals of Kaelé (Far North), Bankim (Adamaoua) and Ntui (Centre)) and urban areas (district hospitals of Bafia (Centre), Edéa (Littoral), Yaoundé 'Centre), Douala (Littoral), Bangangté, Foumban and Dschang (West)) [27].

\section{Inclusion criteria}

Children with oral temperature $\geq 38^{\circ} \mathrm{C}$, fever $<7$ days with at least one of specific symptoms (Head ache, joint pain, back ache, abdominal pain, vomiting, fatigue, anorexia and diarrhea), aged 4 months to 15 years recorded in the clinic regardless of gender, ethnicity or tribe, were included (Additonal file 1).

\section{Exclusion criteria}

Children admitted in the hospital for known diseases or with fever of more than seven days and, above the age of 15 years were excluded.

\section{Sample size determination}

The size of the population was determined using the following formula: $n=Z^{2} P Q / d^{2}$, where $n$ is the sample size, $\mathrm{P}$ the prevalence, $\mathrm{Q}$ is $1-\mathrm{P}, \mathrm{Z}$ is the statistic level of confidence (1.96), d is precision (0.05) [28]. P-value was considered as $50 \%$, representing maximum uncertainty [29]. Hence, the estimated sample size was 384.

\section{Sample collection and processing}

Plasma was obtained after centrifugation of the blood ( $3 \mathrm{~mL})$ of each patient, collected by venepuncture and introduced into EDTA tubes. Aliquots of each plasma were prepared in cryovial plain tubes and stored at $20{ }^{\circ} \mathrm{C}$. for subsequent analyzes.

\section{Laboratory test for dengue infection}

Each plasma was analysed for the detection of NS1 antigen and for the detection of IgM antibodies using a Tell me fast $^{\circ}$ Combo Dengue NS1-IgG/IgM Rapid Test (Biocan Diagnostics Inc. Canada). The interpretation of the RDTs results was done in conformity with the manufacturer's instructions. IgM and IgG antibodies against DENV were confirmed using an in-house indirect ELISA assay, as previously described [27, 30]. 
A confirmed acute dengue case was defined by the detection of the DENV NS1 protein alone or DENV NS1 protein with IgM antibodies or DENV NS1 protein with IgG antibodies against DENV in plasma samples of children with fever illness and at least one of the following symptoms: head ache, joint pain, back ache, abdominal pain, vomiting, fatigue, anorexia and diarrhea [26, 31, 32].

\section{Statistical analysis}

The data from the operation of the questionnaire administered to the participants (spplement material) were processed statistically using the Graphpad Prism software. Seropositivity rates were caloked by considering acute dengue cases, characterized by the presence of NS1 antigen alone or associated with IgG / IgM. The Chi2 test was used to identify the associations between the different independent variables and their significance levels. Using bivariable logistic regression, we examined the effects of wearing long sleeve shirts and trousers, using indoor insecticide sprays and covering household water container on the odds of seropositivity were examined.

\section{Results}

In this study, 961 febrile children were screened for seroprevalence of acute DENV using a Tell me fast ${ }^{\circ}$ Combo Dengue NS1-IgG/IgM Rapid Test (Biocan Diagnostics Inc. Canada). As shown in Table 1, out of the 961 febrile children tested, 494 (51.4\%) were males and $467(48.6 \%)$ females, with a general age mean $( \pm$ SD) $7.1 \pm 2.9$ years and age ranged from (min-max) of four months- 15 years. Almost half of the subjects, $48.8 \%$ (469/ 961) were aged between one and five years, followed by those aged above five years, 43.8\% (421/961). The children under one year old made up to $7.4 \%$ (71/961). A large portion, $61.4 \%(590 / 961)$ of febrile children included in the study lived in urban areas.

Noticeably, and as shown in Table 2, the febrile children who were seropositive for DENV-NS1 antigen (acute dengue: $n=59 / 961,6.14 \%$ ) were subdivided as follows: $5.1 \%$ (3/59) of children showed mono-positivity to DENV-NS1 alone; $84.7 \%(50 / 59)$ and $10.2 \%(6 / 59)$ of them showed dual positivity to DENV-NS1 plus antiDENV IgM or IgG antibodies respectively. The subjects under one year were not positive to acute dengue marker (Table 2). However, children aged above one year predominantly expressed acute dengue. Nevertheless, acute dengue was not significantly associated with the age groups of children $(P=0.0815)$ (Table 2$)$. The prevalence of acute dengue in females, $7.7 \%$ (36/467), was significantly higher $(P=0.0488)$ than in males, $4.7 \%(23 /$ 494). On the other hand, the prevalence of acute dengue in children living in urban areas, 5.9\% (35/590) (Bafia, Edea, Yaoundé, Douala, Bangangté, Foumban and Dschang) was significantly not different $(p=0.7357)$ from that of the subjects living in semi-urban areas, $6.5 \%(24 / 371)$ (Table 2). Among the study sites, Ntui showed the highest frequency of dengue virus markers with $9.8 \%(7 / 71)$ of infections, while the subjects living in Foumban were less exposed, with just 4.0\% (4/101) of dengue virus markers.

Concerning the risk factors related to acute dengue in this study (Table 3), it was shown that $10.3 \%(52 / 503)$ of children who did not consistently cover their household water containers were positive for dengue virus markers, whereas those who cover their own were acute dengue positive at $1.5 \%$ (7/458). Furthermore, dengue virus markers were significantly $(p=0.0001)$ more prevalent among children who did not regularly wear long-sleeved shirts and pants $(15.1 \%$; 42/278) compared to those who did not wear them $(2.5 \% ; 17 / 683)$. The same trend has been observed among those who live in houses where insecticide is regularly sprayed $(16.1 \%$; $38 / 236)$, compared to those who live in houses where this practice is not common $(2.9 \%$; $21 / 725)$. There was also a statistical significance between the frequent wearing of long sleeve shirts with trousers and the presence of dengue virus markers $(p=0.0001)$. The level of Dengue virus markers was also relatively higher in patients who did not use indoor insecticide spray with a prevalence rate of $16.1 \%$ (38/236) compared to their counterparts who frequently used these insecticides sprays with a prevalence of $2.9 \%$ (21/725). Furthermore, there was a statistical difference between the frequent use of indoor insecticide sprays and the presence of dengue virus markers $(p=0.0001)$. Preventive behaviors such as the wearing of long sleeve shirts and trousers and the use of indoor insecticide spray obviously was associated with reduced risk of dengue infection in children (by 83.53 and $82.73 \%$ ) by the mosquito bites with a relative risk (RR) of 0.1647 and 0.1727 respectively. Practices such as covering household water containers limited mosquito proliferation, and

Table 1 Socio-demographic representation of the study population

\begin{tabular}{|c|c|c|c|c|c|}
\hline \multirow[t]{2}{*}{ Variables } & \multicolumn{2}{|l|}{ Gender } & \multicolumn{3}{|l|}{ Age groups } \\
\hline & Females $(n=467)$ & Males $(n=494)$ & 4 mth-1 yr $(n=71)$ & $1-5$ yrs $(n=469)$ & $6-15$ yrs $(n=421)$ \\
\hline Semi urbain (\%) & 185 (39.6) & $189(38.3)$ & $36(50,7)$ & $100(21.3)$ & $238(56.5)$ \\
\hline Urbain (\%) & $282(60.4)$ & $305(61.7)$ & 35 (49.3) & 369 (78.7) & $183(43.5)$ \\
\hline
\end{tabular}

mth: months, yr.(s)year(s) 
Table 2 Distribution of acute dengue, serological markers in febrile children according to different variables

\begin{tabular}{|c|c|c|c|c|c|c|c|}
\hline \multirow{2}{*}{ Variables } & & & \multirow[b]{2}{*}{ Children with acute dengue (\%) } & \multicolumn{3}{|c|}{ Dengue serological markers } & \multirow[b]{2}{*}{$P$-value (Chi-square) } \\
\hline & & & & NS1 (\%) & NS1 + lgM (\%) & NS1 + lgG (\%) & \\
\hline \multirow[t]{2}{*}{ Gender } & \multicolumn{2}{|c|}{ Female $(n=467)$} & $36(7.7)$ & $1(0.2)$ & $34(7.3)$ & $1(0.2)$ & $0.0488^{*}(3.88)$ \\
\hline & \multicolumn{2}{|c|}{ Male $(n=494)$} & $23(4.7)$ & $2(0.4)$ & $16(3.2)$ & $5(1.0)$ & \\
\hline \multirow[t]{3}{*}{ Age groups } & \multicolumn{2}{|c|}{4 mth-1 yr $(n=71)$} & 0 & $0(0.0)$ & $0(0.0)$ & $0(0.0)$ & $0.0815^{\mathbf{a}}(5.015)$ \\
\hline & \multicolumn{2}{|c|}{$1-5$ yrs $(n=469)$} & $31(6.6)$ & $3(0.6)$ & $26(5.5)$ & $2(0.4)$ & \\
\hline & \multicolumn{2}{|c|}{$6-15$ yrs $(n=421)$} & $28(6.6)$ & $0(0.0)$ & $24(5.7)$ & $4(0.9)$ & \\
\hline \multirow[t]{10}{*}{ Residence } & \multirow[t]{3}{*}{ Semi-urban } & Kaele $(n=150)$ & $10(6.7)$ & $1(0.7)$ & $7(4.7)$ & $2(1.3)$ & $0.7357^{\mathbf{b}}(0.1139)$ \\
\hline & & Bankim $(n=150)$ & $7(4.7)$ & $1(0.7)$ & $5(3.3)$ & $1(0.7)$ & \\
\hline & & Ntui $(n=71)$ & $7(9.8)$ & $0(0.0)$ & $5(7.0)$ & $2(2.8)$ & \\
\hline & \multirow[t]{7}{*}{ Urban } & Bafia $(n=60)$ & $4(6.7)$ & $0(0.0)$ & $3(5.0)$ & $1(1.7)$ & \\
\hline & & Edea $(n=68)$ & $4(5.9)$ & $1(1.5)$ & $3(4.4)$ & $0(0.0)$ & \\
\hline & & Yaounde $(n=85)$ & $8(9.4)$ & $0(0.0)$ & $8(9.4)$ & $0(0.0)$ & \\
\hline & & Douala $(n=77)$ & $4(5.2)$ & $0(0.0)$ & $4(5.2)$ & $0(0.0)$ & \\
\hline & & Bangangte $(n=96)$ & $5(5.2)$ & $0(0.0)$ & $5(5.2)$ & $0(0.0)$ & \\
\hline & & Foumban $(n=101)$ & $4(4.0)$ & $0(0.0)$ & $4(4.0)$ & $0(0.0)$ & \\
\hline & & Dschang $(n=103)$ & $6(5.8)$ & $0(0.0)$ & $6(5.8)$ & $0(0.0)$ & \\
\hline
\end{tabular}

mth months, yr.(s) year(s), prevalence of acute Dengue with respect to the residence

consequently reduced the risk of dengue infection in children with a relative risk of 0.1478 , they were thus protected $(85.22 \%)$.

\section{Discussion}

The diagnosis of dengue requires either the direct detection of the virus or the detection of specific antibodies. While the use of molecular methods, including PRC, is not always easy to implement in developing countries, the ELISA method for the detection of NS1 antigen or specific IgG and IgM antibodies is easier to implement and at relatively low cost. The NS1 protein is an early marker of dengue infection and can be used to diagnose the disease in its acute phase [33, 34]. The use of this marker in this study allowed the prevalence of the acute dengue to be estimated at $6.14 \%$; its combination with the detection of specific IgM increases the level of diagnostic sensitivity of acute dengue, which contributes to take rapid clinical decisions [35]. The prevalence obtained shows that dengue infection is responsible for a relatively large proportion of febrile states in children in Cameroon and that such diagnosis should be practiced even in rural areas. Fortunately, the Dengue NS1-IgG/ IgM based RDTs Combo can be easily implemented in rural areas with good efficacy [36].

The prevalence value of acute dengue fever obtained in this study is very close to that reported by Nasir et al. $(8.8 \%)$, in febrile patients at the University Hospital of Abuja (Nigeria) [37], but lower than those of $35 \%$ reported in Ibadan [38], 77.1\% in Nnewi [39] and 30.8\% in Kwara state in Nigeria [40]. Thus, the differences observed could result from the fact that, unlike the present study, some of these authors have relied on the detection of dengue-specific IgM to identify acute dengue cases,

Table 3 Evidence of dengue infection in febrile children according to risk factors

\begin{tabular}{|c|c|c|c|c|}
\hline Risk factors & DENV Positive (\%) & DENV Negative (\%) & $p$-value & RR $(95 \% \mathrm{Cl})$ \\
\hline Covered household water container & & & $0.0001^{*}$ & $0.1478(0.0678-0.32)$ \\
\hline Yes $(n=458)$ & $7(1.5)$ & $451(98.5)$ & & \\
\hline No $(n=503)$ & $52(10.3)$ & $451(89.7)$ & & \\
\hline Frequency of wearing long sleeve shirts and trousers & & & $0.0001^{*}$ & $0.1647(0.0249-0.2844)$ \\
\hline Yes $(n=683)$ & $17(2.5)$ & $666(97.5)$ & & \\
\hline No $(n=278)$ & $42(15.1)$ & $236(84.9)$ & & \\
\hline Frequency of indoor insecticide sprays & & & $0.0001^{*}$ & $0.1727(0.0702-0.2884)$ \\
\hline Yes $(n=725)$ & $21(2.9)$ & $704(97.1)$ & & \\
\hline No $(n=236)$ & $38(16.1)$ & $198(83.9)$ & & \\
\hline
\end{tabular}


which in the absence of the NS1 antigen may refer only to a secondary dengue and thus a late diagnosis $[13,41]$. Nevertheless, false positive results of NS1 antigen detection have been reported for this dengue protéin in a patient with acute Zika virus infection [42] while regions of cross-reactivity with Zika virus have not yet been tested. For this reason, it is better to combined dengue-specific antigen (NS1) and specific antibodies (IgM and IgG) to increase the diagnosis rates for dengue [23, 43, 44]. This study showed that children under one year of age were less affected by dengue fever while $6.6 \%$ of older children were dengue positive, consistent with earlier findings in Nigeria [45]. The explanation for this trend lies in the fact that the mosquito vector of dengue mainly stings out of the houses. For example, one-year-old children, in addition to being better protected, are rarely found outside homes where they are more likely to come into contact with mosquitoes. The prevalence of acute dengue fever was significantly higher in women than in men, which is consistent with recent studies in Indonesia and Thailand [38, 46-48], but contrasts with another study in India [49].

In the present state of knowledge, no studies on hospital seroprevalence of acute Dengue have been reported in Cameroon. In this study, a relative higher prevalence of acute dengue was observed in children who did not adopt various protective measures against the mosquito bites, compared to those who practiced some protective measures such as frequency of wearing long sleeve shirts and trousers as well as frequency of indoor insecticide sprays. These observations may are in line with previous studies carried out in Pakistan [49-51] but contrast with those of Mustapha et al. [52] who realized no association between dengue virus infection and protective measures.

Finally, we would have probably found more acute dengue among febrile children in Cameroon if children with febrile illness in all health centers were included in the study. Dengue RT-PCR serotype and molecular characterization strains should be used in the study environment.

\section{Conclusion}

Dengue is a neglected disease and. This study has reported seroprevalence of acute dengue among febrile children in Cameroon for the first time. The low seroprevalence of acute dengue in the study population may be an indication of potential endemicity of the infection in the general population of the country. The results of this study show that dengue fever is potentially endemic in Cameroon, suggesting that appropriate measures should be taken by public health officials to limit children's exposure to risk factors. In addition, we suggest that the diagnosis of dengue be included in routine examinations of febrile children in Cameroon hospitals to avoid the occurrence of epidemics in the population. Lastly, a special attention should be paid to the epidemiological surveillance of this viral infection in Cameroon.

\section{Additional file}

\section{Additional file 1: Fact Sheet for participant data collection.}

(DOCX $15 \mathrm{~kb})$

\section{Abbreviations}

DENV: Dengue virus; DHF: Dengue haemorrhagic fever; DSS: Dengue shock syndrome; ELISA: Enzyme linked Immunosorbent assay; IgG: Immunoglobulin G; IgM: Immunoglobulin M; NS1Ag: Non-structural antigen; RNA: Ribonucleic acid; RT-PCR: Reverse transcriptase polymerase chain reaction

\section{Acknowledgments}

The authors would like to thank all the health facilities for their administrative authorizations. Our special thanks and appreciation also go to all the study participants who voluntarily participated in this study. We also thank the personnel of the Public school of medical laboratory Technicians, Yaoundé, (Cameroon) for the consistent support with some reagents and other materials during this work. Special thanks go to Mr. Lissom Abel for the statistical analysis, Dr. Inoncent Mbulli Ali who read the manuscript and Dr. Gilbert Tagne Safotso who accepted to read the final version of the manuscript for language edition.

\section{Authors' contributions}

GWN, JRK, SBT, and TFT designed research; SBT and JCT performed literature searches; SBT, TFT, JCT, EPA, MZB, MIMF and ESM, performed research; SBT and TFT analyzed data and wrote the paper, GWN and JRK finalised the paper. All authors read and approved the final manuscript

\section{Funding}

The authors received no financial support for the research and writing of this manuscript.

\section{Availability of data and materials}

The datasets used and/or analyzed during the current study are available from the corresponding author on reasonable request.

\section{Ethics approval and consent to participate}

Ethical clearance for this study was obtained from the Cameroon National Ethics Committee for Research on Human Subjects (Ethical Clearance number $N^{\circ}$ 2014/12/530/CE/CNERSH/SP). Written assents from all parents or guardians of each children less than 16 years of age participating in this study were sought and obtained after explaining the risks during venepuncture, the benefits, and the right to refuse participation or to decline any question item. Demographic data such as name, address, sex, age, temperature, symptoms and risks factors were collected with a designed questionnaire [27]

\section{Consent for publication}

Not applicable.

\section{Competing interests}

The authors declare that there is no competing interest.

\section{Author details}

${ }^{1}$ Department of Biochemistry, University of Dschang, Dschang, Cameroon. ${ }^{2}$ Laboratory of Vaccinology/Biobanking, CIRCB, Melen Yaoundé, Cameroon. ${ }^{3}$ Public School of Medical Laboratory Technicians, Yaoundé, Cameroon. ${ }^{4}$ Department of Animal Biology and Physiology, University of Yaoundé 1, Yaoundé, Cameroon. ${ }^{5}$ Ministry of Public Health, Yaoundé, Cameroon.

${ }^{6}$ FOSACO-IFSTMS, Yaoundé, Cameroon. 
Received: 1 February 2019 Accepted: 28 June 2019 Published online: 18 July 2019

\section{References}

1. Chen R, Vasilakis N. Dengue--quo tu et quo vadis? Viruses. 2011;3(9):1562-608.

2. Kamgang B, Yougang AP, Tchoupo M, Riveron JM, Wondji C. Temporal distribution and insecticide resistance profile of two major arbovirus vectors Aedes aegypti and Aedes albopictus in Yaounde, the capital city of Cameroon. Parasit Vectors. 2017;10(1):469.

3. Kamgang B, Happi JY, Boisier P, Njiokou F, Herve JP, Simard F, Paupy C. Geographic and ecological distribution of the dengue and chikungunya virus vectors Aedes aegypti and Aedes albopictus in three major Cameroonian towns. Med Vet Entomol. 2010;24(2):132-41.

4. Simard F, Nchoutpouen E, Toto JC, Fontenille D. Geographic distribution and breeding site preference of Aedes albopictus and Aedes aegypti (Diptera: culicidae) in Cameroon, Central Africa. J Med Entomol. 2005;42(5):726-31.

5. Kamgang B, Nchoutpouen E, Simard F, Paupy C. Notes on the bloodfeeding behavior of Aedes albopictus (Diptera: Culicidae) in Cameroon. Parasit Vectors. 2012;5:57.

6. Paupy C, Brengues C, Kamgang B, Herve JP, Fontenille D, Simard F. Gene flow between domestic and sylvan populations of Aedes aegypti (Diptera: Culicidae) in North Cameroon. J Med Entomol. 2008;45(3):391-400.

7. Anand AM, Sistla S, Dhodapkar R, Hamide A, Biswal N, Srinivasan B. Evaluation of NS1 antigen detection for early diagnosis of dengue in a tertiary Hospital in Southern India. Journal of clinical and diagnostic research : JCDR. 2016;10(4):DC01-4.

8. Eckerle I, Kapaun A, Junghanss T, Schnitzler P, Drosten C, Janisch T. Dengue virus serotype 3 infection in traveler returning from West Africa to Germany. Emerg Infect Dis. 2015;21(1):175-7.

9. Jaenisch T, Junghanss T, Wills B, Brady OJ, Eckerle I, Farlow A, Hay SI, McCall PJ, Messina JP, Ofula $V$, et al. Dengue expansion in Africa-not recognized or not happening? Emerg Infect Dis. 2014;20.

10. Amarasinghe A, Kuritsk JN, Letson GW, Margolis HS. Dengue virus infection in Africa. Emerg Infect Dis. 2011;17(8):1349-54.

11. Institut National de la Statistique du Cameroun 2016. Annuaire statistique du Cameroun 2016 [http://www.statistics-cameroon.org/news.php?id=476].

12. Tsai TF, Lazuick JS, Ngah RW, Mafiamba PC, Quincke G, Monath TP. Investigation of a possible yellow fever epidemic and serosurvey for flavivirus infections in northern Cameroon, 1984. Bull World Health Organ. 1987, 65(6):855-60.

13. Simmons CP, Farrar JJ, Nguyen $\vee V$, Wills B. Dengue. N Engl J Med. 2012;366(15):1423-32.

14. Akbar NA, Allende I, Balmaseda A, Coelho IC, da Cunha RV, Datta B, Devi SS, Farrar J, Gaczkowski R, Guzman MG et al.: Regarding "dengue-how best to classify it". Clin Infect Dis 2012, 54(12):1820-1821; author reply 1821-1822.

15. Simmons $C P$, Chau TN, Thuy $\Pi$, Tuan NM, Hoang DM, Thien NT, Lien le B, Quy NT, Hieu NT, Hien T, et al. Maternal antibody and viral factors in the pathogenesis of dengue virus in infants. J Infect Dis 2007;196(3):416-24.

16. Halsey ES, Williams M, Laguna-Torres VA, Vilcarromero S, Ocana V, Kochel TJ, Marks MA. Occurrence and correlates of symptom persistence following acute dengue fever in Peru. Am J Trop Med Hyg. 2014:90(3):449-56.

17. Thomas L, Najioullah F, Verlaeten O, Martial J, Brichler S, Kaidomar S, Moravie V, Cabie A, Cesaire R. Relationship between nonstructural protein 1 detection and plasma virus load in dengue patients. Am J Trop Med Hyg. 2010;83(3):696-9.

18. Young PR, Hilditch PA, Bletchly C, Halloran W. An antigen capture enzyme-linked immunosorbent assay reveals high levels of the dengue virus protein NS1 in the sera of infected patients. J Clin Microbiol. 2000;38(3):1053-7.

19. Shrivastava A, Dash PK, Tripathi NK, Sahni AK, Gopalan N, Lakshmana Rao PV. Evaluation of a commercial dengue NS1 enzyme-linked immunosorbent assay for early diagnosis of dengue infection. Indian J Med Microbiol. 2011;29(1):51-5.

20. Kumarasamy V, Chua SK, Hassan Z, Wahab AH, Chem YK, Mohamad M, Chua KB. Evaluating the sensitivity of a commercial dengue NS1 antigencapture ELISA for early diagnosis of acute dengue virus infection. Singap Med J. 2007;48(7):669-73.
21. Alcon S, Talarmin A, Debruyne M, Falconar A, Deubel V, Flamand M. Enzyme-linked immunosorbent assay specific to dengue virus type 1 nonstructural protein NS1 reveals circulation of the antigen in the blood during the acute phase of disease in patients experiencing primary or secondary infections. J Clin Microbiol. 2002;40(2):376-81.

22. Kassim FM, Izati MN, TgRogayah TA, Apandi YM, Saat Z. Use of dengue NS1 antigen for early diagnosis of dengue virus infection. Southeast Asian J Trop Med Public Health. 2011;42(3):562-9.

23. Dussart P, Labeau B, Lagathu G, Louis P, Nunes MR, Rodrigues SG, StorckHerrmann C, Cesaire R, Morvan J, Flamand M, et al. Evaluation of an enzyme immunoassay for detection of dengue virus NS1 antigen in human serum. Clin Vaccine Immunol. 2006;13(11):1185-9.

24. Peeling RW, Artsob H, Pelegrino JL, Buchy P, Cardosa MJ, Devi S, Enria DA, Farrar J, Gubler DJ, Guzman MG, et al. Evaluation of diagnostic tests: dengue. Nat Rev Microbiol. 2010;8(12 Suppl):S30-8.

25. Hunsperger EA, Yoksan S, Buchy P, Nguyen VC, Sekaran SD, Enria DA, Pelegrino $J$, Vazquez S, Artsob H, Drebot M, et al. Evaluation of commercially available anti-dengue virus immunoglobulin $\mathrm{M}$ tests. Emerg Infect Dis. 2009;15(3):436-40.

26. Mahesh Kumar S, Sheethal S. Comparison of NS1 antigen detection by ICT and ELISA for evaluating acute dengue. IntJCurrMicrobiolAppSci. 2018;7(02):3652-6

27. Tchuandom SB, Tchouangueu TF, Antonio-Nkondjio C, Lissom A, Ngono Djang JO, Atabonkeng EP, Kechia A, Nchinda G, Kuiate J-R. Seroprevalence of dengue virus among children presenting with febrile illness in some public health facilities in Cameroon. Pan African Med J. 2018;31.

28. Pourhoseingholi MA, Vahedi M, Rahimzadeh M. Sample size calculation in medical studies. Gastroenterol Hepatol Bed Bench. 2013;6(1):14-7.

29. Macfarlane SB. Conducting a descriptive survey: 2. Choosing a sampling strategy. Trop Dr. 1997;27(1):14-21.

30. Lissom A, Ouambo FH, Megnekou R, Okeke MI, Ngu LN, Netongo PM, Ngoh AA, Sanders CA, Bawage S, Tchouangeu FT, et al. Comparative analysis of igg responses to recombinant Q $\beta$ phage displayed MSP3 and UB05 in dual HIV-malaria infected adults living in areas differing in malaria transmission intensities. J Clin Exp Immunol. 2019;4(1).

31. WHO: Dengue: Guidelines for Diagnosis, Treatment, Prevention and Control, vol. New edition: WHO Press; 2009.

32. Pires Neto Rda J, de Sa SL, Pinho SC, Pucci FH, Teofilo CR, Evangelista PD, The CS, Bezerra DE, Lima JC, Ponte HJ, et al. dengue infection in children and adolescents: clinical profile in a reference hospital in Northeast Brazil. Rev Soc Bras Med Trop. 2013;46(6):765-8.

33. Andries AC, Duong V, Ngan C, Ong S, Huy R, Sroin KK, Te V, Y B, Try PL, Buchy P. Field evaluation and impact on clinical management of a rapid diagnostic kit that detects dengue NS1, IgM and lgG. PLoS Negl Trop Dis. 2012;6(12):e1993.

34. Hunsperger EA, Sharp TM, Lalita P, Tikomaidraubuta K, Cardoso YR, Naivalu T, Khan AS, Marfel M, Hancock WT, Tomashek KM, et al. Use of a rapid test for diagnosis of dengue during suspected dengue outbreaks in resourcelimited regions. J Clin Microbiol. 2016;54(8):2090-5.

35. Andries AC, Duong V, Ong S, Ros S, Sakuntabhai A, Horwood P, Dussart P, Buchy $P$. Evaluation of the performances of six commercial kits designed for dengue NS1 and anti-dengue $\operatorname{lgM}$, IgG and IgA detection in urine and saliva clinical specimens. BMC Infect Dis. 2016:16:201.

36. Shukla MK, Singh N, Sharma RK, Barde PV. Utility of dengue NS1 antigen rapid diagnostic test for use in difficult to reach areas and its comparison with dengue NS1 ELISA and qRT-PCR. J Med Virol. 2017;89(7):1146-50.

37. Nasir IA, Agbede OO, Dangana A, Baba M, Haruna AS. Dengue virus nonstructural Protein-1 expression and associated risk factors among febrile patients attending University of Abuja Teaching Hospital, Nigeria. Virus Res. 2017;230:7-12.

38. Oyero OG, Ayukekbong JA. High dengue NS1 antigenemia in febrile patients in Ibadan, Nigeria. Virus Res. 2014;191:59-61.

39. GO C, JS A, OM C, PO M, RS E, JC A, JC A, GI A, GW N, CO E. Seroprevalence of dengue virus among children with febrile illness in Nnewi, Nigeria. J Med Res. 2018:4(1):24-30

40. Adedayo F, Nioma I, Olanrewaju MB, Adeyinka A, Ebele A, Adedayo F, Nioma I, Olanrewaju MB, Adeyinka A, Ebele A. Serological evidence of recent dengue virus infection among febrile children in a semi arid zone. Am J Infect Dis. 2013;9:7-10.

41. Peeling RW, Smith PG, Bossuyt PM. A guide for diagnostic evaluations. Nat Rev Microbiol. 2010;8(12 Suppl):S2-6. 
42. Gyurech D, Schilling J, Schmidt-Chanasit J, Cassinotti P, Kaeppeli F, Dobec M. False positive dengue NS1 antigen test in a traveller with an acute Zika virus infection imported into Switzerland. Swiss Med Wkly. 2016;146:w14296.

43. Wang SM, Sekaran SD. Evaluation of a commercial SD denque virus NS1 antigen capture enzyme-linked immunosorbent assay kit for early diagnosis of denque virus infection. J Clin Microbiol. 2010;48(8):2793-7.

44. Hu D, Di B, Ding X, Wang Y, Chen Y, Pan Y, Wen K, Wang M, Che X. Kinetics of non-structural protein $1, \lg M$ and $\lg G$ antibodies in dengue type 1 primary infection. Virol J. 2011;8:47.

45. Fagbami AH, Monath TP, Fabiyi A. Dengue virus infections in Nigeria: a survey for antibodies in monkeys and humans. Trans R Soc Trop Med Hyg 1977;71(1):60-5

46. Kalayanarooj S, Gibbons RV, Vaughn D, Green S, Nisalak A, Jarman RG, Mammen MP Jr, Perng GC. Blood group AB is associated with increased risk for severe dengue disease in secondary infections. J Infect Dis. 2007;195(7):1014-7.

47. Rigau-Perez JG, Clark GG, Gubler DJ, Reiter P, Sanders EJ, Vorndam AV. Dengue and dengue haemorrhagic fever. Lancet. 1998;352(9132):971-7.

48. Basuki PS, Budiyanto PD, Husada D, Darmowandowo W, Ismoedijanto SS, Yamanaka A. Application of revised dengue classification criteria as a severity marker of dengue viral infection in Indonesia. Southeast Asian J Trop Med Public Health. 2010:41(5):1088-94.

49. Wali JP, Biswas A, Handa R, Aggarwal P, Wig N, Dwivedi SN. Dengue haemorrhagic fever in adults: a prospective study of 110 cases. Trop Dr. 1999;29(1):27-30.

50. Mahmood S, Nabeel H, Hafeez S, Zahra U, Nazeer H. Seroprevalence of dengue IgG antibodies among healthy adult population in Lahore, Pakistan. ISRN Tropical Medicine. 2013;2013:1-6.

51. Mahmod M, Darul ND, Mokhtar I, Nor NM, Anshar FM, Maskon O. Atrial fibrillation as a complication of dengue hemorrhagic fever: non-self-limiting manifestation. Int J Infect Dis. 2009;13(5):e316-8.

52. Mustapha JO, Emeribe AU, Nasir IA. Survey of malaria and anti-dengue virus IgG among febrile HIV-infected patients attending a tertiary hospital in Abuja, Nigeria. HIV AIDS (Auckl). 2017;9:145-51.

\section{Publisher's Note}

Springer Nature remains neutral with regard to jurisdictional claims in published maps and institutional affiliations.

Ready to submit your research? Choose BMC and benefit from:

- fast, convenient online submission

- thorough peer review by experienced researchers in your field

- rapid publication on acceptance

- support for research data, including large and complex data types

- gold Open Access which fosters wider collaboration and increased citations

- maximum visibility for your research: over $100 \mathrm{M}$ website views per year

At $\mathrm{BMC}$, research is always in progress.

Learn more biomedcentral.com/submissions 